\title{
Analisis perilaku off-task siswa
}

\author{
Yeni Elviza Febrianti ${ }^{*}$, Neviyarni Suhaili $^{2}$ \\ ${ }^{12}$ Universitas Negeri Padang
}

\begin{tabular}{|c|c|}
\hline Article Info & ABSTRACT \\
\hline Article history: & \multirow{5}{*}{$\begin{array}{l}\text { Penelitian ini bertujuan untuk menganalisis perilaku off-task remaja sekolah } \\
\text { menengah pertama. Penelitian ini menggunakan deskriptif kuantitatif. Sampel } \\
\text { penelitian ini terdiri dari } 50 \text { siswa, yaitu } 25 \text { siswa perempuan dan } 25 \text { siswa laki- } \\
\text { laki. Penelitian ini menggunakan analisis univariat. Hasil penelitian yang } \\
\text { menggunakan angket perilaku off-task menunjukkan setengah dari responden } \\
\text { berada pada kategori perilaku off-task rendah. Tipe tertinggi perilaku off-task } \\
\text { yaitu perilaku off-task motoric. }\end{array}$} \\
\hline Received Nov $06^{\text {th }}, 2020$ & \\
\hline Revised Des $24^{\text {th }}, 2020$ & \\
\hline Accepted Jan $13^{\text {th }}, 2021$ & \\
\hline $\mathbf{V w}$ & \\
\hline
\end{tabular}

Perilaku Off-task

C 2021 The Authors. Published by IICET.

This is an open access article under the CC BY-NC-SA license

(https://creativecommons.org/licenses/by-nc-sa/4.0)

\section{Corresponding Author:}

Yeni Elviza Febrianti, Universitas Negeri Padang

Email: yeniharahap7699@gmail.com

\section{Pendahuluan}

Pendidikan dan pengajaran merupakan sebuah proses yang sadar akan tujuan. Salah satu hal yang melatarbelakangi mengapa prestasi tidak dapat tercapai secara optimal adalah masalah yang berkaitan dengan belajar siswa. Tingkah laku belajar dalam situasi belajar di kelas ada yang tidak dikehendaki kemunculannya yaitu tingkah laku yang disebut perilaku off-task (Sukiman, 2005). Suatu jenis perilaku yang mempengaruhi pembelajaran siswa, dimana siswa melepaskan diri sepenuhnya dari lingkungan belajar dan melibatkan diri pada hal-hal yang tidak berkaitan dengan belajar (Baker, 2007; Denok \& Setiawati, 2003). Perilaku off-task merupakan perilaku di mana siswa benar-benar melepaskan diri dari tugas, untuk terlibat dalam perilaku lain yang tidak sesuai dengan kegiatan belajar (Triastuti, N., \& Indrijati, H. 2015).

Perilaku off-task dapat disebabkan oleh berbagai faktor, diantaranya: 1) untuk mendapatkan perhatian orang dewasa, teman sebaya, atau bahkan memberikan kesempatan untuk melakukan aktivitas yang lebih disukai, seperti berbicara dengan teman atau bermain dengan benda-benda 2) untuk melarikan diri atau menghindari kegiatan yang tidak diinginkan, seperti menulis atau membaca, 3) dapat terjadi pada siswa yang mengalami gangguan neuro-behavioral seperti sindrom tourette atau attention deficit disorder. Gejala umum penyebab perilaku off-task adalah kurangnya minat siswa dalam belajar dan strategi pembelajaran yang diberikan oleh guru kurang bervariasi (Halimah, Bakar, Nurbaity, 2020). Selain itu, Ketidakpahaman siswa tentang materi pembelajaran dan tugas yang sulit juga memicu siswa untuk memunculkan perilaku off-task (Armbruster, 2011). Pendapat tersebut diperkuat dengan pernyataan Moor \& Sweeney yang menyatakan bahwa tugas yang terlalu sulit akan memunculkan perilaku off-task (Clevenger, 2008).

Pemberian tugas yang terlalu sulit pada siswa dapat menyebabkan siswa memunculkan perilaku off-task dalam kelas karena ketika siswa tidak paham dengan tugas yang diberikan maka siswa akan melakukan aktivitas-aktivitas lain untuk mengisi waktunya. Aktivitas serupa juga dilakukan oleh siswa yang memperoleh pembelajaran di bawah tingkat kecerdasannya (Woolfolk, 2009). 
Berdasarkan beberapa penjelasan tersebut, dapat disimpulkan bahwa faktor-faktor yang mempengaruhi perilaku off-task terdiri dari dua yaitu faktor internal dan eksternal. Faktor internal merupakan faktor yang berasal dari dalam diri individu itu sendiri, yaitu emosional yang mencakup di dalamnya kepribadian temperamental, kemarahan, penentangan, ketegasan, frustrasi, kecemasan, ketakutan, kebosanan, overstimulasi, kebutuhan akan perhatian, kecemburuan, dan rendah diri. Selain itu juga fisiologis yang mencakup di dalamnya gizi buruk, kelaparan, kelelahan, penyakit, dan alergi. Sedangkan faktor eksternal adalah faktor yang berasal dari luar individu tersebut, yaitu faktor keluarga, sekolah dan masyarakat.

Penelitian yang dilakukan oleh Baker (2004) kepada 5 kelas Sekolah Menengah Pertama (SMP) di Amerika, di dapatkan dari dua sekolah yang berbeda menunjukkan bahwa ada $66 \%$ siswa yang tidak sungguhsungguh mengikuti pembelajaran di kelas. Survei yang dilakukan oleh Zenius Education yang dimulai bulan September hingga Desember tahun 2014 dengan judul "Survei pandangan siswa/i tentang sekolah, guru, dan orangtua" berhasil mengumpulkan jawaban dari 1340 siswa pelajar dari seluruh pelosok Indonesia yaitu dari Aceh hingga Manado. Siswa mengaku bahwasanya hal yang dilakukan di dalam kelas selain mengikuti kegiatan belajar adalah melakukan kegiatan lain yang tidak ada kaitannya dengan belajar. Mereka suka gosip dengan teman, bukan soal pelajaran. Selain bergosip, sebagian siswa mengaku tidak bisa lepas dari smartphone, main game, mendengarkan musik, chatting sama pacar atau orang, sampe update status dan foto selfie ke media sosial. Bukan hanya itu, penelitian yang dilakukan oleh Resty, Thalib, Munifah (2018) terhadap siswa SMP 18 Palu menunjukkan bahwa kelas VII yang paling banyak melakukan perilaku off-task pada saat jam pembelajaran, yaitu dengan seringkali mendapati siswa saling berbicara satu dengan yang lain ketika guru sedang mengajar, berjalan kesana kemari di dalam kelas ketika ada guru, bercerita saat jam pelajaran, tidur di dalam kelas ketika guru mengajar, tidak mengerjakan tugas yang diberikan oleh guru, ada juga siswa yang hanya melamun ketika guru menjelaskan pelajaran dan perilaku menyimpang lainnya. Perilaku off-task dipengaruhi oleh pikiran irasional yang menyebabkan verbalisasi diri yang tidak tepat (Dewi, 2016; Baker \& Butler, 1984) Hal ini berdasarkan pada asumsi Meichenbaum (Baker \& Butler, 1984) yang menyatakan bahwa individu mengalami perilaku salah dikarenakan pikiran irasional yang diakibatkan kesalahan dalam melakukan verbalisasi diri.

Perilaku off-task meliputi perilaku mengganggu yang dilakukan dengan gerakan-gerakan, berbicara maupun tidak melakukan aktivitas apapun saat proses pembelajaran. Bentuk-bentuk dari perilaku off-task terdiri dari tiga aspek yaitu off-task motoric behaviors, off-task verbal behaviors, dan off-task passive behaviors Off-task motoric behaviors adalah aktivitas di luar pembelajaran yang dilakukan oleh siswa dan cenderung mengganggu jalannya proses belajar dengan melakukan gerakan-gerakan tubuh yang berlebihan, seperti berjalan-jalan saat proses belajar, melempat-lempat kertas, keluar masuk ruangan. Off-task verbal behaviors adalah aktivitas di luar pembelajaran yang dilakukan oleh siswa dan cenderung mengganggu dengan melibatkan kata/kalimat yang dilontarkan selama proses belajar di kelas berlangsung, seperti berbicara kotor, bersiul, bersendawa, ataupun bernyanyi saat belajar di kelas. Off-task passive behaviors adalah aktivitas di luar pembelajaran yang dilakukan oleh siswa dengan tidak terlibat dalam kegiatan kelas dan engggan terlibat dalam proses pembelajaran yang sedang berlangsung, seperti melamun, tertidur, menatap keluar ruangan sehingga membuat tugas yang diberikan guru tidak dapat di selesaikan (Shapiro, 2004).

Dampak dari perilaku off-task dapat merugikan siswa. Kerugian-kerugian bagi siswa berperilaku off-task menunjukkan bahwa siswa yang memiliki perilaku off-task harus segera diberikan intervensi untuk dapat mereduksi perilakunya tersebut, tanpa dilakukannya intervensi pada siswa yang berperilaku off-task, maka perilaku ini akan cenderung memburuk, memiliki resiko yang lebih serius pada masalah sepanjang hidup (Widiastuti, 2017; Meany-Wallen, 2015). Selain itu, perilaku off-task ini berdampak pada pembelajaran siswa di berbagai tingkat. Pada tingkat individu proses belajar siswa tersebut mungkin terbengkalai saat ia tidak berhasil melatih keterampilan yang diajarkan di kelas. Pada tingkat kelompok, gangguan yang mungkin terjadi ketika siswa keluar dari tempat duduk adalah menimbulkan lebih banyak siswa untuk memilih melakukan perilaku off task dan mungkin pada akhirnya menghasilkan sebagian kecil pelanggaran serius terhadap kelas dan peraturan sekolah (Shofuah, 2016). Selain itu, perilaku off-task dapat menghambat keberhasilan belajar (David \& Nicholas, 2011). Berdasarkan beberapa fenomena dan beberapa pendapat para ahli tersebut, untuk itu peneliti tertarik untuk mengungkapkan bagaimana perilaku off-task siswa di SMP Islam Terpadu Padangsidimpuan.

\section{Metode}

Penelitian ini merupakan jenis penelitian deskriptif kuantitatif yang bertujuan untuk mendeskripsikan tingkat perilaku off-task pada remaja. Penelitian ini di lakukan di SMP IT Darul Hasan Padangsidimpuan. Populasi dalam penelitian ini adalah seluruh kelas VIII dengan jumlah sampel 50 responden menggunakan teknik purposive sampling. Penelitian ini menggunakan analisis univariat, yang mana dalam penelitian ini akan 
menunjukkan data demografi responden, jenis kelamin dan analisis hasil pertanyaan masing-masing kategori pada kuesioner perilaku off-task remaja. Validitas instrument dilakukan pada telaah construct validity dan content validity, kemudian meminta judgement experts yaitu orang yang memiliki keahlian dalam bidang penyusunan instrument untuk menilainya. Sedangkan, untuk menguji validitas butir (isi) menggunakan teknik Spearman's rho.

\section{Hasil dan Pembahasan}

Perilaku off-task yang dilakukan remaja memiliki proporsi yang hampir sama, dengan jumlah reponden lakilaki dan perempuan sama yaitu laki-laki $50 \%$ dan perempuan $50 \%$. Hal ini sesuai dengan penelitian Dwi Safitri (2016) terhadap siswa kelas VIII di SMPN 1 Lengkong-Nganjuk bahwa beberapa siswa kelas VIII sering melakukan perilaku off-task di beberapa mata pelajaran. Dapat dilihat pada tabel 1 berikut.

Tabel 1. Distribusi frekuensi statistic responden

\begin{tabular}{lll}
\hline Jenis Kelamin & F & $\%$ \\
\hline Laki-laki & 25 & 50 \\
\hline Perempuan & 25 & 50 \\
\hline Total & 50 & 100 \\
\hline
\end{tabular}

Tabel 2. Kategori Perilaku Off-task

\begin{tabular}{|c|c|c|c|c|c|c|}
\hline \multirow{3}{*}{ Kategori } & \multicolumn{4}{|c|}{ Jenis Kelamin } & \multirow{3}{*}{$\mathbf{F}$} & \multirow{3}{*}{$\%$} \\
\hline & \multicolumn{2}{|c|}{ Laki-laki } & \multicolumn{2}{|c|}{ Perempuan } & & \\
\hline & $\mathbf{F}$ & $\%$ & $\mathbf{F}$ & $\%$ & & \\
\hline Perilaku Off-task Sangat Rendah & 4 & 16 & 4 & 16 & 8 & 16 \\
\hline Perilaku Off-task Rendah & 10 & 40 & 10 & 40 & 20 & 40 \\
\hline Perilaku Off-task Sedang & 7 & 28 & 8 & 32 & 15 & 30 \\
\hline Perilaku Off-task Tinggi & 3 & 12 & 3 & 12 & 6 & 12 \\
\hline Perilaku Off-task Sangat Tinggi & 1 & 4 & 0 & 0 & 1 & 2 \\
\hline Total & 25 & 100 & 25 & 100 & 50 & 100 \\
\hline
\end{tabular}

Tabel 2 menunjukkan bahwa responden laki-laki dan perempuan mempunyai peluang yang sama untuk melakukan perilaku off-task. Hampir setengah dari responden berada pada tingkat perilaku off-task rendah yaitu sebanyak 20 responden (40\%) berada pada kategori rendah. Jumlah siswa dengan kategori perilaku off-task sedang yaitu sebanyak 15 responden (30\%), dan tinggi berjumlah 6 responden (12\%), dari 41 responden tersebut, jika dijumlahan responden laki-laki dan perempuan yang melakukan perilaku off-task sedang dan tinggi adalah 21 responden (42\%) dengan perincian 15 responden dengan kategori sedang dan 6 responden dengan kategori tinggi. Namun perilaku off-task dengan kategori sangat tinggi sejumlah 1 responden (2\%). Melihat hasil penelitian di atas, dapat ditarik kesimpulan bahwa antara siswa laki-laki dan siswa perempuan memiliki peluang yang sama untuk melakukan perilaku off-task saat belajar di kelas.

Responden laki-laki dan perempuan lebih banyak melakukan perilaku off-task motoric yang dapat mengganggu proses pembelajaran dan menghambat siswa untuk dapat mengerjakan tugas tepat waktu. Hal ini dapat dilihat pada tabel 3 berikut.

Tabel 3. Distribusi frekuensi Responden berdasarkan aspek-aspek perilaku off-task siswa.

\begin{tabular}{lll}
\hline Kategori & F & \% \\
\hline Perilaku Off-task Motoric & 20 & 40 \\
\hline Perilaku Off-task Verbal & 15 & 30 \\
\hline Perilaku Off-task Passive & 15 & 30 \\
\hline Total & 50 & 100 \\
\hline
\end{tabular}

Tabel 3 menunjukkan bahwa jumlah siswa dengan perilaku off-task passive dan perilaku off-task verbal sebanyak 15 responden (30\%), sedangkan siswa dengan perilaku off-task motoric sebanyak 20 responden (40\%). 
Melihat hasil penelitian tersebut, dapat ditarik kesimpulan bahwa perilaku off-task motoric memiliki tingkat frekuensi lebih tinggi dibandingkan perilaku off-task passive dan off-task verbal. Adapun perilaku off-task motoric yang sering dilakukan siswa adalah dengan berjalan-jalan saat belajar di kelas, menggoda teman saat belajar di kelas, menulis/menggambar di buku tulis sesuatu yang tidak berkaitan dengan tugas pembelajaran, serta tidak mau mengerjakan tugas dikelas. Hal ini sesuai dengan penelitian Hanike (Puspaningtyas, 2010) beberapa perilaku off task antara lain (a) melamun (daydreaming); (b) tidur dalam kelas; (c) berjalan-jalan di kelas; (d) menggoda teman; (e) bermain-main sendiri (memainkan kertas, pensil, atau alat-alat yang tidak ada hubungannya dengan pelajaran); (f) berbincang dengan teman tentang sesuatu yang tidak ada hubungannya dengan pelajaran; (g) tidak mau mengerjakan tugas dikelas (membolos) pada pelajaran tertentu; (j) bertengkar dengan teman di kelas (Sintiasari, D.W. I., Nursalim (2018).

Pada tabel 1 terlihat bahwa responden laki-laki dan responden perempuan memiliki proporsi yang sama, yaitu laki-laki 50\% dan perempuan 50\%. Hal ini sesuai dengan penelitian Dwi Safitri (2016) terhadap siswa kelas VIII di SMPN 1 Lengkong-Nganjuk bahwa beberapa siswa kelas VIII sering melakukan perilaku off-task di beberapa mata pelajaran. Selain itu, penelitian yang dilakukan oleh Riyadi (2015) menyatakan bahwa siswa laki-laki maupun siswa perempuan dengan jumlah 36 melakukan perilaku off-task yaitu $8 \%$ gaduh dan suka mengobrol sesama teman, $22 \%$ bercanda dengan teman, $53 \%$ tidak fokus memperhatikan penjelasan guru, $28 \%$ suka bernyanyi-nyanyi di kelas.

Perilaku off-task yang sering dilakukan siswa adalah perilaku off-task motoric, yaitu perilaku yang dilakukan siswa yang mengganggu jalannya proses belajar dengan melakukan gerakan-gerakan tubuh yang berlebihan. Penelitian ini diperkuat dengan penelitian yang sebelumnya bahwa bentuk perilaku off-task peserta didik yang paling dominan yaitu keluar masuk ruangan yaitu siswa yang tidak dapat mengontrol diri dan kurangnya sikap disiplin belajar, padahal disiplin merupakan hal yang penting, karena apabila sikap disiplin dapat kita terapkan pada kehidupan sehari-hari maka akan membawa dampak yang baik pada diri sendiri. Disiplin sangat penting bagi setiap individu, karena dapat digunakan untuk memotivasi dalam mendisiplinkan diri dalam melaksanakan kegiatan (Halimah, 2020)

Penelitian lain juga mengatakan bahwa bentuk perilaku motoric yang sering dilakukan siswa seperti bermain gadget tanpa diketahui oleh guru yang mengajar, tidak menyelesaikan tugas, tidak memperhatikan guru saat mendemontrasikan materi, serta meminjam atau mengambil alat tulis teman tanpa ijin (Safitri, 2015). Selain itu, perilaku verbal dan passive juga menjadi perilaku yang sering dilakukan siswa saat proses belajar. Perilaku tersebut dapat muncul secara spontan akibat siswa merasa kurang tertarik dengan mata pelajaran, guru, dalam menggunakan materi pelajaran yang kurang inovatif, sampai kondisi ruangan yang kurang representative. Hal ini menunjukkan bahwa daya konsentrasi belajar siswa mulai menurun dan keterlibatan intelektuan-emosional siswa mulai berkurang (Maulana, 2019).)

\section{Simpulan}

Hasil penelitian ini menunjukkan variasi perilaku off-task pada siswa laki-laki dan siswa perempuan. Perilaku off-task yang dilakukan oleh siswa memiliki ciri khas yang berbeda dan memiliki kecendrungan perilaku off-task yang bervariasi antara perilaku off-task motoric, perilaku off-task verbal, ataupun perilaku off-task passive.

\section{Referensi}

Armbruster. (2011). Issue: off-task behavior. University of Pitsburgh

Baker, R. S. (2007). Modeling and understanding students' off-task behavior in intelligent tutoring systems. In Proceedings of the SIGCHI conference on Human factors in computing systems (pp. 1059-1068).

Baker, R. S., Corbett, A. T., Koedinger, K. R., \& Wagner, A. Z. (2004). Off-task behavior in the cognitive tutor classroom: when students" game the system". In Proceedings of the SIGCHI conference on Human factors in computing systems (pp. 383-390).

Baker, S.B. \& Butler, J.N. (1984). Effects of preventive cognitive self-instruction training on adolescent attitudes. Experiences, and social anxiety. Journal of Primary Prevention, 5(1),hlm. 17-25.

Clevenger, Rebecca Pate, dkk. (2008). Improvement of task behavior of elementary and high school students through the use of cooperative learning strategies. Chicago: Master of arts in teaching and leadership.

Dewi, F.A, Adi Atmoko, Triyono. 2016. Keefektifan teknik self-instruction dalam konseling kognitif-perilaku untuk meningkatkan efikasi diri sosial siswa SMKN 2 Malang. (Online), Vol. 1, No. 4: 172-178 dipublikasikan pada situs http://journal2.um.ac.id/index.php/jkbk/article/view/611. 
Dwi Safitri, I. K. A. (2016). Penerapan Teknik Self-control Untuk Mengurangi Perilaku Off-task Siswa Kelas VIII Di SMPN 1 Lengkong-nganjuk. Jurnal BK UNESA, 6(2).

Halimah, H., Nurbaity, N., \& Bakar, A. (2020). Analisis Faktor Penyebab Perilaku Off-Task Siswa. JIMBK: Jurnal Ilmiah Mahasiswa Bimbingan \& Konseling, 5(1).

Maulana, M.A. (2019). perilaku Off-task dalam Pembelajaran. Advice:Jurnal Bimbingan dan Konseling, 1(1), 3037.

Meany-Wallen, K. Kottman, T. Bullis, Q \& Taylor, D. (2015). Group adlerian play therapy with children with off-task behaviors. The journal for specialist in group.

Putri Sintiasari, D.W. I., Nursalim, M. (2018). Konseling Individu Teknik Kontrak Perilaku untuk Mengurangi Perilaku Off-task Siswa Kelas VIII-D SMP Negeri 2 Gresik. Jurnal BK UNESA, 9(1)

Resty, M., Thalib, M., \& Munifah, M. (2018). Efektivitas konseling kelompok disertai penguatan dalam mengatasi perilaku menyimpang (off task behavior) dalam proses pembelajaran siswa SMP negeri 18 Palu. Jurnal Konseling dan Psikoedukasi, 3(2), 86-100.

Safitri, I. D. 2005. Penerapan Teknik Self-control Untuk Mengurangi Perilaku Off-task Siswa Kelas VIII Di SMPN 1 Lengkong-nganjuk. Jurnal Mahasiswa Bimbingan Konseling UNESA, 6(2).

Sukiman, dkk. (2005). Pengubahan off task behavior ke on task behavior di kelas melalui penerapan bimbingan berbasis ekologi. Kudus: Universitas Muria Kudus.

Shapiro, E. S., \& Christine L. C. (1994). Behavior change in the classroom: self- management interventions. New York: The Guilford Press.

Shofuhah, M. (2016). Perilaku siswa yang tidak dikehendaki (off-task behavior) dan penanganan konselor di Sdit At-taqwa Surabaya. Jurnal BK UNESA, 6(2).

Triastuti, N., \& Indrijati, H. (2015). Penguatan Positif Untuk Mengurangi Perilaku Off-Task Saat Penugasan Di Kelas Pada Siswa Lamban Belajar Di Sekolah Dasar".

Woolfolk. (2009). Educational psychology. active learning edition tenth edition. Boston: Allyn \& Bacon.

Riyadi, S. (2015). Teknik bermain peran untuk mengurangi perilaku off-task dalam layanan informasi. Jurnal Penelitian Tindakan Bimbingan \& Konseling, 1(1).

Setiawati, Denok. (2013). Penerapan Tekhnik Self Instruction Untuk Mengurangi Perilaku off-Task Siswa. BK UNESA 4: 259-2655. 